\title{
THE USE OF DATA IN POLICY-MAKING IN NIGERIA'S EDUCATIONAL SECTOR: IMPLICATIONS FOR NATIONAL DEVELOPMENT
}

\author{
Dominic Azuh", Segun Joshua ${ }^{2}$, Jide Ibietan ${ }^{2}$ \\ ${ }^{1}$ Department of Economics and Development Studies, Covenant University (NIGERIA) \\ ${ }^{2}$ Department of Political Science and International Relations, Covenant University (NIGERIA)
}

\begin{abstract}
Policy making simply denotes the use of resources to meet public concern. Suffice to say that the act of policy making is an act of political compromise among policy makers. Policy making is a tool to direct the course of educational system of any country towards achieving desired ends. If wrong policies are made in directing the course of education, the result will be educational maladministration which will have adverse effects on the learners with long term implication for national development. It is therefore not a surprise that developed countries of the world are very careful in making sure that educational policies are guided by relevant data. However, developing countries are lagging behind in the use of data-driven for policy making as far as educational sector is concerned. Using public choice theory as an explanatory tool, with secondary data gathering techniques, the paper finds that policies on education are hardly based on data, hence educational policies have not been able to deliver the goal of development as data that are necessary to guide policy making on education are hardly gathered and used.
\end{abstract}

Keywords: Policy, National Development, Education, Data, Maladministration.

\section{INTRODUCTION}

One of the hallmarks of Millennium Development Goals (MDGs) was education which is the bedrock to socio-economic and political development of a nation. Education serves as a catalyst both for individual self-actualization, economic growth and national development. The relevance of education is to meet the needs of the individuals and those of the society in consonance with the changing environmental scenario. Good education base could transform a country from a low per capita income to a high per capita level and from a low human development index to a very high development index. Conceptually, education may be defined as the process by which an individual acquires the many physical and social capabilities demanded of him by the group into which he is born and within which he must function [1]. Education according to Orobosa [2] is an ultimate value and hence through the provision of social service, it is an agent of change. Federal Government of Nigeria [3] has considered education to be an instrument 'per excellence' for effecting national development. As a demographer, education brings changes in demographic dynamics in a society, opens up opportunities for both individual and group empowerment leading to human development. It is a vital tool for transformation and key to sustainable development of a nation. Human capacity development anchored on strong learning systems which is central to the attainment of any goal or vision. Education is the most crucial instrument for empowering young people with knowledge and skills which in turn provide them access to productive employment in future. Policy is a plan of action agreed, chosen or adopted by government for a particular issue; or a formalized set of procedures designed to guide behavior.

Policy making on one hand, is the process by which government translates their political, economic, social, education or health vision into programs, projects and actions to deliver outcomes and desire changes in real world for implementation by human resource. It is evidence that for a policy to be effective it must be based on facts and facts set standards/benchmarks for evaluation which nurtures policies. Education policy is therefore an intended goals and outcomes which government wishes to achieve at various educational levels. Machin and Vignoles [4] note that the poor and apparently falling standards in school, poor skills and persistent inequalities in education are due to deficiency in education policy.

Development concept is captured as a multidimensional process involving major changes in social structures, popular attitude and national institutions as well as the acceleration of economic growth. It involves reduction of inequality or eradication of absolute poverty among the citizenry. Development today represents a whole gamut of change by which an entire social system tuned to the diverse basic 
needs and desires of individuals and social groups within that system moves away from a condition of life widely perceived as unsatisfactory towards a situation or condition of life regarded as materially and spiritually better (Todaro and Stephen [5]. Development implies the ability of a nation to expand its output at a rate faster than the growth rate of its population. This is facilitated through high level of educational sector driven by continual human capital development and technological capacity through research and development.

The success of any system of education is hinged on proper planning through the use of data. The need for data based policy making in national educational sector is more now than before particularly with the current revolution in information and communications technology which has made the world to become a global village. The inconsistencies observed in most educational sector decisions might make one infer that these decisions were based on incomplete information, intuition or rule of the thumb. Education data, like other social data, facilitates planning and constitute invaluable inputs for computing important social indicators which are used to monitor trends in the quality leading to improvement in policy decisions of the sector and better impact. Discovery of where gaps are in education or where we need to concentrate more energy are all product of use and evaluation of data. Unfortunately, Nigeria's education system is in dire need of data based policy formulation that will restore the ailing system. It is the data based policy decision making in education that will ensure better returns on educational investment and stimulate economic growth and national development.

Human resource plays an immense role in the success or failure of any organization or society. There had been disgusting decline in the standard of education over the last $3 / 2$ decades. No doubt all the stake holders have contributed variously to this decline, yet the arrow head of this misfortune may be traced to the chronic and inconsistent policy devoid of informed data use in deriving policies. Data is the grave instrument in deriving effective policy and without data educational policy and management will be mere experimental. Incidentally, Nigeria's educational sector is in a very big confusion, without effective planning and implementation of its strategies leading to non-realization of the developmental dividend of education.

The main objectives of the paper are to examine if educational policies are based on data as this will manifests in greater improvement in the educational sector; and to examine the factors militating against access or use of data in policy making decisions.

\section{AN OVERVIEW OF NIGERIA'S PHILOSOPHICAL FOUNDATION OF EDUCATION}

The 1979 Constitution of the Federal republic of Nigeria manifests the philosophy of her love for education, as Chapter 11, Section 18 of the Constitution re-affirms the objectives ensuring i) equal and adequate educational opportunities for all at all levels of the educational system; ii) promotion of science and technology and iii) eradication of illiteracy through the provision of free compulsory universal primary education, and free university education, and free adult literacy program.

Western education was introduced into Nigeria in the 1840 s by Christian Missionaries. It began in Lagos, Calabar and other coastal cities and later colonial masters established additional schools. Western-style education was not prominent in the northern part of Nigeria, which was predominantly Muslim populated, rather Islamic schools were in place as they preferred Islamic education. Prior to Nigeria's independence, Nigeria had only two established Post-secondary Institutions. Yaba Higher College (founded in 1934, Now Yaba College of Technology) and the University of Ibadan was founded in 1948. It was then a College of the University of London until two years after the independence when she became autonomous. Other institutions came on board such as University of Nigeria, Obafemi Awolowo University (formerly University of Ife), Ahmadu Bello University and University of Lagos. In 1970s more universities were founded which include University of Benin (founded in 1970), and new university opened in Calabar, llorin, Jos, Port Harcourt, Sokoto and Maiduguri. In the 1980s and 1990s the number increased and the list goes on till 2015 with the recent Federal Government approval of 9 new private universities in May 2015. While the estimated enrollment in all these institutions including primary schools, secondary schools and tertiary institutions keep rising, the facilities and infrastructure keep going down. Educational system in Nigeria is structured into three stages namely 6 years of primary school education, 5 to 7 years of postprimary school education and 4 to 6 yrs of tertiary education as per 1981 National Policy on Education. The policy was broadened in 1985, to 6-3-3-4 system and again in 2004, Nigerian education policy was changed to 9-3-4 system. According to UNESCO [6] Nigeria's education reform 
of 2006 shifted focus to entrepreneurship and skill training and realignment of curricula to meet emerging need of a global economy and knowledge society.

The poor state of education in Nigeria has been due to years of neglect and inconsistent policy change. Historically, between 1991 and 1999 the nation passed through five different regimes (Babangida till 1993, Shonekan for less than four months in 1993, Abacha 1993-1998, Abubakar 1998-1999, Obasanjo 1999-2007). Needless to state that as the transition come and goes, successors jettison the policy works of their predecessors leading to gross incongruous educational policies. With such level of instability the end products at all levels lack in quality and required skills needed to make innovative impact. Despite efforts by federal government, donor agencies and Non- governmental organizations in this sector, wide disparity persist in educational standards and learning achievements with a rising surge of mediocrity which threatens every aspect of development.

The targets of various education policies have been missed such as the Education for All (EFA) goal of achieving gender parity at the primary and secondary education levels by 2005 and Millennium Development Goal 2 by 2015 respectively. More so there has been no transformative invention over the years by the tertiary institutions rather employers are complaining that Nigerian graduates are lacking in industrial skills needed for higher productivity. The national mass literacy campaign and Open University of Nigeria were established in 1980 and 1982 respectively to address the problem of access to education. The Babangida's administration introduced the Structural Adjustment Program (SAP) in 1986 which led to all manners of programs in institutions of higher learning including proliferation of satellite campuses. In addition, the gate of establishing public and Private Universities has also been widely opened since 1999, perhaps due to politics than socio- economic and development needs.

The problems facing educational institutions in Nigeria affect its economy and developmental activities. It may not be completely out of place to say that the problems facing the economy of Nigeria as a nation are reflections of the poor quality of human development and management. This is because education which plays a critical role in human development and the economic health of the nation has been either neglected or tampered with for decades (Krueger and Lindhal, [7]; Dike, [8]). Our policies are not based on data, they are hastily conceived and poorly implemented leading to no impact on the citizenry. Nwagwu [9] noted that we jump from one education policy to another in utter confusion and apparent mindlessness and hence we often cannot even wait to see to the maturation and effectiveness of one policy before we abandon it for a new one projected and hailed as the panacea of not only the problems of the educational system but also of the ills of the society itself.

There is dire need for a good understanding of the process of policy formulation and implementation based on data or current statistics. Even the reforms to higher education can only improve quality if it is done through informed policy decision born out of reliable data. Research based policy/decisionmaking is most impactful in transforming the educational landscape for realization of the socioeconomic development that quality education attracts. The decline of our educational standards and the decay of the whole system within the last two and half decades or more is pathetic. The whole setting has been mismanaged, misguided policy choices, poor governance, poorly trained university graduates, high level of unemployment, antisocial behaviors and lots of other vices. The educational landscape of Nigeria has undergone many stages since independence due to several inconsistent changes in policies and programs.

\subsection{Educational Policies and Programs after Independence}

There are several policies and programs established by federal government of Nigeria to put education in its rightful place but unfortunately none of them has been able to achieve the expected objectives. Some of these include:

The Nigerian policy on education had gone through many stages and changes to the extent that, policy incoherence had negatively affected the success of the policies (Lawal, [10]). The national policy on education which was first published in 1977 and revised in 1981 which focused on selfrealization, individual and national efficiency, national unity with the objective of achieving social, cultural, economic, political, scientific and technological development. It was structured into three stages as namely primary school education (6 years), post primary school education (5 to 7 years) and third stage being tertiary education (4 to $6 \mathrm{yrs}$ ). In 2004, Nigerian education policy was redefined to adopt education as an instrument par excellence for effecting national development. 
The Nigeria's education reform of 2006 shifted focus to entrepreneurship and skill training and realignment of curricula to meet emerging need of a global economy and knowledge society (UNESCO [5]). The reform introduced the 9-3-4 system of education which was referred to as the Universal Basic Education (UBE). The four stages were compressed to three, with the first two stages of the former policy merged to one during which education was made compulsory. The first 9 years was referred to as basic and compulsory education (primary and junior secondary), the next 3 years was for the senior secondary school and the last was the four years in the tertiary institutions. The universal primary education, a national project started with Obasanjos' regime in 1976 during the military rule and also changed to UBE during Obasanjo's administration in 2006 to provide education for the Nigerian citizens by changing the content of the UPE to encompass the following philosophy of education as articulated in the National Policy on Education. The UPE program was eventually abandoned mid-way and the current UBE is also having several challenges and not fulfilling its objectives. Other policies or programs that brought about low quality output of Nigeria's educational system are government takeover of Christian missionary schools in 1970, discriminatory policies of state governments when states were created, discriminatory policies and quota system on entry requirements for admission to schools at all levels and catchment policy.

\subsection{Theoretical Framework}

Public Choice Theory is a body of theory developed by James Buchanan and Gordon Tullock to try to explain how public decisions are made. It involves the interaction of the voting public, the politicians, the bureaucracy and political action committees. There are several segments to this theory. The general theoretical theme has been the inefficiency of bureaucracies because of the principal-agent problems inherent in bureaucratic structures and the inability to constrain bureaucracies to the appropriate size because of agenda control on the part of government managers. If a bureaucracy can offer an all or nothing choice with respect to its services, it can grow to the point where most of the consumer surplus from those services can be extracted. Public choice analysis has roots in positive analysis ("what is") but is often used for normative purposes ("what ought to be") in order to identify a problem or suggest improvements to constitutional rules (Tullock, [11]; Downs, [12]; and Niskanen, [13]).

\section{ESSENCE OF DATA USE IN EDUCATIONAL DECISION MAKING AND PLANNING}

Data based policy making ensures accountability in the management of education. Poor planning and non-use of data for policy decision-making is predominant in the educational sector and empirical information/ reports are rare. According to Adeyemi and Oguntimehin [14], there are not enough experts in Nigeria in the area of educational planning. There are small units in the ministries of education, which are responsible for educational planning. These units are often staffed with educational officers who rose from the rank. Almost all of them have no formal training in educational planning and statistics. They can rarely use the information gathered to interpret the educational situation of the country for proper planning of educational reform to improve educational quality. Akinwumiju [15] points out that evaluation is the process of delineating, obtaining and providing useful information for judging among decision alternatives. According to Ajayi [16], lack of accurate statistical data and unreliable national census has tended to render most efforts relating to educational planning or any other forms of planning in Nigeria unproductive. Some studies have observed that data use can lead to school improvement in terms of increased student achievement levels (Carlson, Borman and Robinson, [17]; Campbell and Levin, [18]). Even the National policy on Education recognize the vital nature of planning which goes with empirical data and states that the success of education is hinged on proper planning, efficient administration and adequate planning (The National policy on Education, [19]). According to Willms ([20]) monitoring data can be used by decision-makers in multiple ways such as to identify specific problems, providing a basis for discussions towards a solution, assess effectiveness of interventions implemented at various levels, give rise to new ideas for influencing policy and practice and help administrators and teachers to reduce inequities.

\section{REVIEW OF LITERATURE}

Timely and reliable data are fundamental to planning and management in education especially in monitoring educational developments. According to ESSPIN ([21]) there is currently a lack of timely, reliable data on basic education on which to effect basic decisions at all levels in the system. 
According to Kazeem and Olusola ([22]) the status of the Nigerian educational system at the moment is unenviable. They observed that the quality and standard are low, limited in its reach and disturbing in its future. These days establishment owed their existence to mere legislative fiats which took virtually no consideration, for physical planning, funding implication, quality control mechanisms and manpower needs. Some of the universities, as a matter of urgency took off in the premises of primary and secondary schools (Adesina, [23]) Olaniyan [24] opined that demand for university education has been growing faster than the available resources. Good education and sound economy are products of data based policy leading to better decision making. Way back in the 1990s Hughes [25] observed that data have become a factor of production equal to land, labor and capital. Stressing the veritable nature of education, Awopegba [26] said for Nigeria to accelerate its socio-economic development there is the deliberate need to focus attention on human capital development through regular interaction of planners, employers and builders of human capital to facilitate the process of meaningful national development. According to Nwagwu [9] observed that our policies are not based on data, they are hastily conceived and poorly implemented leading to no impact.

The Nigerian policy on education had gone through many stages and changes to the extent that, policy incoherence had negatively affected the success of the policies Lawal, [10]. Aladekomo [27] lamented that the lack of policy coherence was a matter of great concern. Whereas Ukeje [28] held the view that the standard had indeed declined significantly, Afolabi [29] argued that, the quality of education determines the quality of the products of its education system and by extension the quality and quantity, pace and level of its development. There has been mismanagement and misguided policy choices in Nigeria's educational sector. For instance there is no clear cut responsibility in the running of the sector as there exists conflict between the Federal, State and Local Government, prevalence of multiple system of education; unstable curriculum and curricular to match industrial needs, national manpower needs; politicization of education among others. Recently, scholars have suggested that data driven decision-making has the potential to increase student performance (Alwin, [30]; Doyle, [31]; Peterson, [32]). In same line, Earl and Katz [33] stated that when school educators become knowledgeable about data use, they can more effectively review their existing capacities, identify weaknesses and better chart plans for improvement. In Nigeria, educational planning has not achieved much in terms of reforming the educational system, despite its advantages, due to myriad of influencing factors Alabi and Okemakinde, [34]. The hasty jettison of such policy, drastically modify or completely abandon it for reasons obvious to the policy makers who are political leaders in power impacts negatively on national development. (Afolabi and Loto [35]. Whether we like it or not, this vital school statistic has to be evoked for effective and efficient planning and administration of our educational system (Duze, [36]).

\section{METHODOLOGY}

The role of data in decision-making is very important and data make decisions to be accurate and relevant. Without data policy formulation and implementation will be useless. It is the life-line of any system as good education and sound economy are products of data based policy making. . Formulating education policies based on faulty demographic information or characteristics may lead to faulty education policy. Faulty education policies may lead to poor policy implementation and attract adverse consequences as in the case of Nigeria. According to Mkpa [37] the greatest administrative obstacles to achieving the set goals of the National Policy on Education have arisen from the use of inadequate or unreliable data in making major policy decisions by various Governments. For this paper, public choice theory was used as an explanatory tool along with secondary data.

\section{NIGERIA'S SCENARIO}

Education is a symbol of development, a channel to prepare learners and teachers to acquire the skills, capacities and potentialities to offer solutions to the myriads of challenges facing mankind particularly in African continent including Nigeria. The socio-economic and developmental indicators of Nigeria, (Table 1) show a worrisome concern. Among all the indicators considered, Nigeria is lagging behind and belongs to the low human development index countries with a human development index value of 0.514 and ranked 152th position out of 188 countries (UNDP Human Development Report [38]). Other indicators manifested similar adverse situation. For instance, Nigeria has a high population growth rate of 2.8 , an unemployment rate of 23.9 and perception of individual well-being of 40 . The percentage of people aged 15 and above who can read and write a short statement on their everyday life is termed the adult literacy rate and it is $51.1 \%$. The enrolment ratio of 
the primary school is 85 percent, secondary education has been reduced to almost half $(44 \%)$ and enrolment at the tertiary level account for an insignificant low proportion (10\%). The poverty level is very high in Nigeria as the population living below income Poverty line (\% PPP\$ 1.25 a day) is 62 . The Federal Government Expenditure (\% of GDP) accounts for the N311.125b (CBN, [39]) and the GDP per Capita 2011 PPP\$ is 5.423. Research and Development Expenditure (\% of GDP) is ridiculously low (0.2). However, Gross Domestic Expenditure on Research and Development, Scientific Publication in leading World Journals and Patents Contribution has no budget. The basis for technological change is the scientific discovery and invention. This is measured by the research and discovery, patents and publications in scientific outlets which not only reflect their overall impact on well-being of the masses but also the quality of learning at tertiary level. A nations development pace is undoubtedly tied to the quality of its education. Incidentally, there is no support in these area and the dividends of education have not been achieved.

Table 1 Nigeria's Status of Educational and Related Indicators.

\begin{tabular}{|l|l|l|}
\hline S/n & Indicators & Rate \\
\hline 1. & Adult Literacy Rate(\% ages 15 and older) & $51.1 \%$ \\
\hline 2. & Gross Enrolment Ratio - Primary & 85 \\
\hline 3. & Gross Enrolment Ratio - Secondary & 44 \\
\hline 4. & Gross Enrolment Ratio - Tertiary & 10 \\
\hline 5. & Federal Government Expenditure (\% of GDP). & $\mathrm{N} 311.12 \mathrm{~b}$ \\
\hline 7. & GDP Per Capita [GDP per Capita 2011 PPP\$] & 5.423 \\
\hline 8. & Population Growth Rate & 2.8 \\
\hline 9. & Research and Development Expenditure (\% of GDP) & 0.2 \\
\hline 10. & Gross Domestic Expenditure on Research and Development & $\mathrm{Nil}$ \\
\hline 11. & Scientific Publication in leading World Journals & $\mathrm{Nil}$ \\
\hline 12. & Patents Contribution & $\mathrm{Nil}$ \\
\hline 13. & Population living below income Poverty line (\% PPP\$ 1.25 a day) & 62.0 \\
\hline 14. & Perception of individual Well-being (\% Standard of Living) & 40 \\
\hline 15 & Unemployment & 23.9 \\
\hline 16. & Human Development Index value & 0.514 \\
\hline
\end{tabular}

Source: Human Development Report, 2015

Central Bank of Nigeria, 2014

\section{SOURCES OF DATA AND USE OF DATA IN POLICY-MAKING IN NIGERIA'S EDUCATIONAL SECTOR}

Data for Nigeria's educational policies are from census data (National Population Commission), National Bureau of statistics, Federal Ministry of Education. These sources may not be having reliable demographic data essentially needed for decision making. Data are essential tools for educational decision-making but most of the sources of data available are either extrapolated or based on census data which are not accurate. Without a reliable baseline demographic data, it becomes difficult to plan. Ololube confirmed the problem of data in Nigeria's educational planning when he said one of the most difficult challenges that educational planners face is the issues of inaccurate statistical data. The quality of technical planning is in most cases inhibited by statistical deficiencies and inaccurate data. Nigerian education systems have failed to effectively plan because of lack of accurate data, which is because of the use of mediocre to prepare data for use in the planning and forecasting processes Ololube, [40]. The place of planning is highly indispensable in educational sector. Ololube noted that for any educational system to truly develop, effective planning is indispensable as education and planning are essential characteristics for effective education (Ololube, [41]. In a similar vein, Chapman and Boothrayd [42] revealed that low data quality is a severe problem hindering education data analysis not only in Kwara state but also in most third world nations and even where the data were of good quality the low level of training of school managers in data analysis constitute a hindrance. In 
fact, many of the changes in educational policies are as a result of poor planning or planning without data.

The problems of data are many, such as corruption, low skilled manpower, unreliable demographic data, non-availability of reliable educational data, politics, multiple and proliferation of educational policies. Mkpa [37] gave a capsule dose of data challenge when he said, perhaps the greatest administrative obstacles to achieving the set goals of the National policy on Education have arisen from the use of inadequate or reliable data in making major policy decisions by various governments. Such decisions have usually been based on purely political whims without sound professional justification, planning, or pilot testing. Examples include the adoption of free education at all levels in 1979 by some States. Not too long ago, there was also sudden spurt in the set-up of State universities and polytechnics; all at a time when payment of primary and secondary schools teachers was near impossible. These are some of the litany of decisions effected without recourse to informed data based.

All the policies and reform programs have not been able to translate into tangible improvement in educational quality; hence, the sector is in dire need of sound and data-based policy that will revamp the ravaged system to meeting its expected return on investment by way of ushering in much desired and needed economic growth and development.

\section{CONCLUSION}

In order to evolve a sustainable educational sector in Nigeria there is need to reorganize our educational system based on the use of data in policy decision-making Good education is evident by greater knowledge base and skill human capital that enhances graduate employability and job mobility of recipients. In Nigeria, graduate unemployment is high and significant proportion of graduates are said to be unemployable due to low skills and competence gaps in the labor market. Despite all the policy reforms and programs the educational sector has not achieved the stated objectives. This implies that the fault may not be on policy availability but on the quality and usage of the available data for policies. Since policies by different governments and implementing agencies in Nigeria are devoid of data based leading to non-delivery of educational goals of development, the paper recommends that Ministry of Education at three tiers of government set up a reliable data generating usage unit (REDAGUU). This unit will ensure that data form the basis of policy decision-making in the education sector. In addition, make sure that every policy decision making personnel in education sector tailors their policies and strategies towards research based data for maximizing meaningful developmental growth.

\section{REFERENCES}

[1] Shewawa (2011). Education and national development in Nigeria. News favourRetrieved June 19, 2013 from: http://newsflavour.com/world/Africa/educati on-and-nation Development.

[2] Orobosa U (2010). Education and national development in Nigeria. Vanguard online community. Retrieved May 30, 2013 from: http://www. Community. Vanguardnger. Com/ profile/UWADIA---- options.

[3] Federal Government of Nigeria (2004). National policy on education. Lagos, NERC press.

[4] Maclim S, Vignoles, A. (2006). Education policy in the UnitedKingdom. Retrieved, May 30, 2013 from: http://www. Cee. Ise. Ac. Uk/ceed.p57.pdf. Options.

[5] Todaro, M, P. and Stephen, C. S. (2009) Economic Development. Pearson Education.

[6] UNESCO (2007). Nigeria 10-Year Strategic Plan for Education: Policy, Cost and Financing Assumptions and their Implications. Working Document. Gwang-Chol Chang Education Sector UNESCO Published in March 2007 by: Division of Education Policies and Strategies, UNESCO 7, ED/EPS/2007/PI/1 March 2007 place de Fontenoy, 75352 Paris 07 SP (France). United Nations Educational, Scientific and Cultural Organization.

[7] Krueger, A. B. and Mikael Lindhal (2001) "Education for Growth, why and for Whom? Journal of Economic literature. Vol 39 (4), pp. 101-136.

[8] Dike, V.E. (2002) "The State of Education in Nigeria and the Health of the Nation" NESG Economic Indicators, Vol 8, No. 1. 
[9] Nwagwu, N. A. (1983). "Educational Policy Formulation and Implementation in Nigeria: A Crisis of Rationale Creation". A paper Presented at the Presidential Conference on Nigeria since Independence. Zaria: Ahmadu Bello University 27-31 March.

[10] Lawal Yekini Olawaiye (2013). Education as an Instrument for Effective National Development: Which Way Nigeria. Business \& Entrepreneurship Journal, (2).2, 2013, pp.27-38.

[11] Tullock, Gordon. (1965). The Politics of Bureaucracy. Washington, D.C.: The Public Affairs Press.

[12] Downs, Anthony. 1967. Inside Bureaucracy. Boston, MA: Little, Brown.

[13] Niskanen, William A., Jr. (1971). Bureaucracy and Representative. Government. Chicago, IL: Aldine-Atherton.

[14] Adeyemi, O.B. and Y.A. Oguntimehin, (2000). Nigeria and the Problems of Planning for Quality Education. In: Fadipe, J.O. and E.E. Oluchukwu (Eds.), Educational Planning and Administration in Nigeria in the $21^{\text {st }}$ Century.

[15] Akinwumiju, J.A., 1996. Performance Evaluation and Accountability for Quality Primary Education. In:Ajayi, A.O. and J.A. Akinwumiju (Eds.), Personnel Performance and Capacity Building, Ibadan. Department of Educational Management. University of Ibadan.

[16] Ajayi, T. (1985). Educational Planning and National Development: The Nigeria experience. A paper presented at the 4th Annual Conference of NERA held between 2nd and 6th November, UNIBEN.

[17] Carlson, D., Borman, G.D., \& Robinson, M. (2011). A multistate district-level cluster randomized trial of the impact of data-driven reform on reading and mathematics achievement. Educational Evaluation and Policy Analysis, 33(3), pp. 378-398.

[18] Campbell, C., \& Levin, B. (2009). Using data to support educational improvement Educational Assessment, Evaluation and Accountability, 21, pp. 47-65.

[19] National Policy on Education (2004). National Policy on Education. (Revised). Federal Ministry of Education. Lagos.

[20] Willms, J. D. (2004). Monitoring School Performance: A Guide for Educators. London:The Falmer Press.

[21] Education Sector Support Programme in Nigeria (ESSPIN) (2009) Approach to supporting EMIS. Position paper Doc. No.: ESSPIN 026.

[22] Kazeem, Kolawole and Ige, Olusola (2010) Redressing the Growing Concern of the Education Sector in Nigeria. Edo Journal of Counselling, 3. (1), pp 40-49.

[23] Adesina, S. (2005). Growth without development: The Nigerian educational experience. Lagos. Yema Investment Ltd.

[24] Olaniyan, O. (2001). Public finance and higher education in Nigeria. Proceedings of the 12th general assembly of the Social Science Academy of Nigeria (SSAN) pp. 101-119.

[25] Hughes, G.C. (1991). The Information age. Information Development. 7(2): pp 72.

[26] Awopegba, P. O. (2001) Human Capital Development in Nigeria: A Socio-Economic Analysis. Nigerian Journal of Clinical and Counselling Psychology: 7 (1/2), pp. 157-167.

[27] Aladekomo Florence O. (2004). Nigeria Educational Policy and Entrepreneurship. Journal of Social Science, 9(2): 75-83.

[28] Ukeje, B. O. (1995). Crisis in the Nigeria education system. Unpublished. Keynote Address at the Nigeria Academy of Education Annual Congress in November at Abuja.

[29] Afolabi, O.A. (2010). Opening Address at the National Examination Summit, held at the National Universities Commission (NUC). Abuja, Nigeria.

[30] Alwin, L. (2002). The Will and the Way of Data Use. School Administrator, 59 (11), pp. 11.

[31] Doyle, D. P. (2003). Data-Driven Decision-Making: Is it the Mantra of the month or Does It Have Staying Power? T.H.E. Journal, 30(10), pp. 19-21. 
[32] Peterson, J. L. (2007). Learning facts: The brave New World of Data-informed instruction. Education Next, 1, 36-42.

[33] Earl, L., \& Katz, S. (2006). Leading schools in a data rich world. Thousand Oaks, CA: Corwin Press. pp. 17.

[34] Alabi, A. O. and T. Okemakinde (2010). Effective Planning as a Factor of Educational Reform and Innovation in Nigeria. Curr. Res. J. Soc. Sci., 2(6): pp.316-321.

[35] Afolabi, F.O. and Loto, A.B. (2012) "Socio-political Vicissitudes and Bureaucratic Constraints on Educational Formulation and Implementation in Nigeria". In Edo, V.O. and Salami, E.F.K. (eds), issues and Trends in Nigeria's Development: A Festschrift for Rev. (Fr.) Abiodun, F.A. Ibadan: John Achers.

[36] Duze CO (2001) Patterns of wastage in primary schools in Delta State of Nigeria (Unpublished Monograph).

[37] Mkpa, M. A. (2013). Overview of Educational Development: Pre-Colonial to Present Day available at http://www.onlinenigeria.com/links/send.asp?blurb=534

[38] UNDP Human Development Report (2015). Work for Human Development.New York: UNDP.

[39] Central Bank of Nigeria (2014). Statistical Bulletin, Vol 25. Abuja: CBN.

[40] Ololube, N. P. (2013). The Problems and Approaches to Educational Planning in Nigeria: A Theoretical Observation. Mediterranean Journal of Social Sciences 4(12).

[41] Ololube, N. P. (2013). Educational management, Planning and Supervision: Models for Effective Implementation. Owerri, Nigeria: SpringField Publishers.

[42] Chapman, D.W. and Boothrayd, R.A. (1988) quality in developing countries settings", Education Review 32 (4) pp 416-429. 